inception. Our thanks are also due to Imperial Chemical Industries PLC, who kindly provided all the tamoxifen (Nolvadex) tablets for the duration of the trial, and, finally, to Miss M J Moores and Miss J L Parsons for typing the manuscript.

Surgeons who participated in the trial were: $M$ A Brennan, K G Buckler, M Crumplin, D G Cowley, H A Daniels (Retd), J Done, J Duthie, A J Farmer, R C Hartley, A Higham, N Hira, W Humphreys, J Kelly, J B Laine, W Lawson, W H Lonsdale, J P Lythgoe, J Main, Miss M T Morrell, W G Paley, J Russell (Retd), A F Robinson, I Sewell, W N Samarji, H F Smith, J S S Stewart, D Teasdale (Retd), L Turner, J B L Taylor, R S Todd, A Watson, J Whitehead, A W Williams (Retd), W Weatherston-Wilson (Retd), and J Yule.

Radiotherapists who participated were: E Allan, M P Cole (Retd), D P Deakin, M B Duthie, R Gibb (Retd), N K Gupta, R D Hunter, R D James, D Pearson, R S Pointon, G Read, G G Ribeiro, E Sherrah-Davies, R Sout, and M L Sutton.
References ${ }^{1}$ Cole MP. A clinical trial of an artificial menopause in carcinoma of the
breast. IN

${ }^{2}$ Cole MP, Jones CTA, Todd IDH. A new anti-oestrogenic agent in late breast cancer. An early clinical appraisal of ICI 46474. Br f Canceß $1971 ; 25: 270-5$.

3 Mouridsen H, Palshof T, Patterson J, Battersby L. Tamoxifen in advancedo breast cancer. Cancer Treat Rev 1978;5:131-41.

${ }^{4}$ Jordan VC, Dowse LJ. Tamoxifen as an anti-tumour agent: effect on oestrogen binding. J Endocrinol 1976;68:297-303.

${ }^{5}$ Lythgoe JP, Leck T, Swindell R. Manchester Regional Breast Study'preliminary results. Lancet $1978 ; \mathrm{i}: 744-7$.

${ }^{6}$ Peto R, Peto J. Asymptotically efficient rank invariant test procedures? fournal of the Royal Statistical Society 1972;A135:185-207.

(Accepted 8 February 1983)

\title{
Effect of metformin on insulin receptor binding and glycaemic control in type II diabetes
}

\author{
J M LORD, S I WHITE, C J BAILEY, T W ATKINS, R F FLETCHER, K G TAYLOR
}

\begin{abstract}
To investigate the effect of metformin on insulin receptor binding and diabetic control, eight obese type II diabetic patients were studied before treatment, after one and four weeks of taking metformin ( $500 \mathrm{mg}$ thrice daily), and four weeks after withdrawal of the drug. After one and four weeks of treatment the number of erythrocyte insulin receptors had increased by $116 \%$ and $184 \%$ respectively. This was due almost entirely to an increase in the number of low affinity binding sites. The number of receptors was still raised four weeks after metformin had been withdrawn. Diabetic control as assessed by urinary glucose, glycosylated haemoglobin $\left(\mathbf{H b} A_{1}\right)$, and glucose tolerance values was significantly improved during metformin treatment, while plasma insulin concentrations were not altered.

These results indicate that metformin produces a rapid and protracted increase in low affinity insulin receptors in type II diabetes, associated with greater insulin sensitivity and improved diabetic control.
\end{abstract}

\section{Introduction}

Metformin has a place in the treatment of type II diabetic patients with normal hepatic and renal function. The drug may be appropriate in obese patients who show an inadequate

\footnotetext{
Department of Biological Sciences, University of Aston in Birmingham, Birmingham B4 7ET

J M LORD, BSC, research fellow

C J BAILEY, PHD, lecturer in physiology

$T$ W ATKINS, PHD, lecturer in biochemistry

Department of Diabetes and Endocrinology and Clinical Investigation Unit, Dudley Road Hospital, Birmingham B18 7QH

S I WHITE, MRCP, senior house officer (now registrar in dermatology, Royal Victoria Infirmary, Newcastle upon Tyne)

R F FLETCHER, FRCP, consultant physician

K G TAYLOR, MD, consultant physician
}

response to diet and in non-obese patients in whom a combination $\vec{N}$ of diet and sulphonylurea has failed to produce glycaemic control

Metformin reduces hyperglycaemia by increasing periphera glucose uptake and reducing hepatic gluconeogenesis. The effect of the drug is achieved without an increase in plasma insulin concentrations, suggesting that it potentiates the action of insulin. ${ }^{1}$ The first step in the cellular mechanism of insulin action is the binding of insulin to receptors in the plasms membrane. Metformin reportedly increases insulin binding to receptors in erythrocytes of normal subjects ${ }^{2}$ and to receptors inf cultured lymphocytes and cultured breast cancer cells. ${ }^{3} \mathrm{~W} \mathbb{Q}_{2}$ report the effect of metformin on erythrocyte insulin receptor binding in type II diabetes in relation to diabetic control.

\section{Patients and methods}

We studied eight obese patients with type II diabetes (mean $137 \cdot 5 \pm$ SEM $10 \cdot 2 \%$ of ideal body weight). Five of the patients were postmenopausal women and three were men, and their mean age waš $61 \cdot 0+4.6$ years. The mean time since diagnosis of their disease was $4.0 \pm 0.8$ years. Each patient was asked to follow a fully structured energy controlled diet from four weeks before the study until itso completion. The diet was designed to maintain a constant body weight throughout. No patient had proteinuria or any biochemical evidences of impaired renal or hepatic function and none received any medication other than metformin. Each patient served as his or her own control: Tests were performed immediately before treatment, after one and four weeks of treatment with metformin (Glucophage, $500 \mathrm{mg}$ thres times a day), and four weeks after the metformin had been withdrawn.w

Patients presented at 0900 after a 12 hour fast. A 24 hour urine collection from the previous day was analysed for the glucose conceneo tration. ${ }^{4}$ Venous blood was collected for measurement of the percent $\frac{-}{-}$ age of glycosylated haemoglobin $\left(\mathrm{HbA}_{1}\right)^{5}$ and plasma concentrations of glucose, ${ }^{4}$ insulin, ${ }^{6}$ and metformin. ${ }^{7}$ A $50 \mathrm{~g}$ oral glucose tolerance testo was performed and blood samples for measurement of plasma glucoseō and insulin concentration taken at 0,30, 60, 90, and 120 minutes.

Erythrocyte insulin receptor binding was determined by the method of Gambhir et al. ${ }^{8}$ Data were analysed after Scatchard ${ }^{9}$ using a mode which assumes two classes of receptors with different but fixed affinities, one exhibiting high affinity and the other low affinity. ${ }^{10}$ Then apparent receptor affinity was taken as the concentration of nativeo insulin required to reduce by $50 \%$ the specific cell bound fraction of ${ }^{125}$ I-insulin. ${ }^{11}$ The different interpretations of insulin receptor binding data have been reviewed elsewhere. ${ }^{12}$ 
TABLE I-Diabetic control before, during, and after treatment with metformin $(3 \times 500 \mathrm{mg}$ daily for four weeks). Values are means \pm SEM. (Eight subjects)

\begin{tabular}{|c|c|c|c|c|c|c|c|c|}
\hline \multirow{2}{*}{ Treatment } & \multirow{2}{*}{$\begin{array}{c}\% \text { Ideal } \\
\text { body weight }\end{array}$} & \multirow{2}{*}{$\begin{array}{c}\text { Plasma } \\
\text { metformin } \\
(\mu \mathrm{g} / \mathrm{ml})\end{array}$} & \multirow{2}{*}{$\begin{array}{c}\text { Urinary } \\
\text { glucose } \\
(\mathrm{mmol} / 24 \mathrm{~h})\end{array}$} & \multirow{2}{*}{$\underset{(\%)}{\mathrm{HbA}_{1}}$} & \multicolumn{2}{|c|}{ Plasma glucose $(\mathrm{mmol} / \mathrm{l})$} & \multicolumn{2}{|c|}{ Plasma insulin $(\mathrm{mU} / \mathrm{l})$} \\
\hline & & & & & $0 \mathrm{~min}$ & $\Sigma \dagger$ & $0 \mathrm{~min}$ & $\Sigma \dagger$ \\
\hline $\begin{array}{l}\text { Pretreatment control } \\
\text { Metformin one week } \\
\text { Metformin four weeks } \\
\text { Metformin withdrawn four weeks }\end{array}$ & $\begin{array}{l}137 \cdot 5 \pm 10 \cdot 2 \\
137 \cdot 6 \pm 10 \cdot 2 \\
138 \cdot 5 \pm 10 \cdot 8 \\
137 \cdot 1 \pm 10 \cdot 3\end{array}$ & $\begin{array}{l}\text { ND } \\
1.45 \pm 0.41 \\
0.94 \pm 0.34 \\
\mathrm{ND}\end{array}$ & $\begin{array}{l}224 \cdot 1 \pm 71 \cdot 9 \\
136 \cdot 1 \pm 49 \cdot 5 \\
77 \cdot 7 \pm 35 \cdot 6^{*} \\
235 \cdot 6 \pm 95 \cdot 3\end{array}$ & $\begin{array}{l}14 \cdot 0 \pm 1 \cdot 1 \\
12 \cdot 4 \pm 1 \cdot 4^{*} \\
12 \cdot 7 \pm 1 \cdot 0 \\
13 \cdot 8 \pm 0 \cdot 7\end{array}$ & $\begin{array}{l}11 \cdot 5 \pm 1 \cdot 0 \\
9 \cdot 6 \pm 0 \cdot 8^{* * *} \\
9 \cdot 1 \pm 0 \cdot 8^{* * *} \\
10 \cdot 8 \pm 1 \cdot 0\end{array}$ & $\begin{array}{l}78 \cdot 2 \pm 5 \cdot 3 \\
65 \cdot 5 \pm 4 \cdot 3^{* * *} \\
62 \cdot 3 \pm 4 \cdot 5^{* * *} \\
76 \cdot 3 \pm 6 \cdot 8\end{array}$ & $\begin{array}{l}13 \cdot 6 \pm 2 \cdot 4 \\
11 \cdot 3 \pm 2 \cdot 2 \\
13 \cdot 4 \pm 1 \cdot 5 \\
14 \cdot 4 \pm 1 \cdot 8\end{array}$ & $\begin{array}{l}125 \cdot 3 \pm 29 \cdot 3 \\
128 \cdot 6 \pm 25 \cdot 3 \\
115 \cdot 3 \pm 15 \cdot 2 \\
121 \cdot 4 \pm 20 \cdot 8\end{array}$ \\
\hline
\end{tabular}

$\mathrm{ND}=$ Not detectable

${ }^{*} \mathrm{p}<0.05,{ }^{* *} \mathrm{p}<0.01, * * * \mathrm{p}<0.001$ compared with pretreatment control (Student's paired $t$ test).

$=$ Sum of plasma glucose or insulin values at $0,30,60,90$, and $120 \mathrm{~min}$ during $50 \mathrm{~g}$ oral glucose tolerance tests.
Conversion: SI to traditional units-Urinary glucose: $1 \mathrm{mmol} / 24 \mathrm{~h} \approx 0.18 \mathrm{~g} / 24 \mathrm{~h}$. Plasma glucose: $1 \mathrm{mmol} / 1 \approx 18 \mathrm{mg} / 100 \mathrm{ml}$.

TABLE II-Erythrocyte insulin receptor binding before, during, and after treatment with metformin $(3 \times 500 \mathrm{mg}$ daily for four weeks). Values are means \pm SEM. (Eight subjects)

\begin{tabular}{lcccc}
\hline \multicolumn{1}{c}{ Treatment } & $\begin{array}{c}\text { Total } \\
\text { receptor } \\
\text { number } \\
\text { per cell }\end{array}$ & $\begin{array}{c}\text { High affinity } \\
\text { receptor } \\
\text { number } \\
\text { per cell }\end{array}$ & $\begin{array}{c}\text { Low affinity } \\
\text { receptor } \\
\text { number } \\
\text { per cell }\end{array}$ & $\begin{array}{c}\text { Apparent } \\
\text { affinity } \\
\text { constant } \\
\text { (nmol/1) }\end{array}$ \\
\hline Pretreatment control & $176 \cdot 1 \pm 30 \cdot 0$ & $36 \cdot 6 \pm 5 \cdot 4$ & $139 \cdot 5 \pm 28 \cdot 7$ & $1 \cdot 08 \pm 0 \cdot 06$ \\
Metformin one week & $381 \cdot 7 \pm 86 \cdot 0^{*}$ & $38 \cdot 6 \pm 3 \cdot 7$ & $343 \cdot 1 \pm 70 \cdot 5^{*}$ & $1 \cdot 03 \pm 0 \cdot 07$ \\
Metformin four weeks & $500 \cdot 6 \pm 77 \cdot 9 * *$ & $46 \cdot 1 \pm 5 \cdot 4$ & $454 \cdot 5 \pm 79 \cdot 9 * *$ & $1 \cdot 20 \pm 0 \cdot 05$ \\
Metformin withdrawn four weeks & $405 \cdot 1 \pm 61 \cdot 1^{* * *}$ & $36 \cdot 3 \pm 5 \cdot 0$ & $368 \cdot 7 \pm 64 \cdot 3^{* *}$ & $1 \cdot 18 \pm 0.08$ \\
\hline
\end{tabular}

${ }^{*} \mathrm{p}<0.05,{ }^{* *} \mathrm{p}<0.01$ compared with pretreatment control (Student's paired $t$ test).

\section{Results}

Table I shows that body weight was maintained throughout the study. Compliance with the metformin treatment was confirmed by the plasma metformin concentrations. Diabetic control was improved during the four weeks of metformin treatment: 24 hour urinary glucose, $\mathrm{HbA}_{1}$, and fasting plasma glucose concentrations were reduced and glucose tolerance improved. Plasma insulin concentrations were not altered by the metformin.

Metformin increased erythrocyte insulin receptor binding in all patients (table II). The total number of insulin receptor binding sites was increased by $116 \%$ after one week and $184 \%$ after four weeks of treatment. This was due almost entirely to an increase in the number of low affinity receptors. There was no alteration of the apparent receptor affinity constant. The effect of metformin on the number of insulin receptors was still evident four weeks after metformin was withdrawn.

\section{Discussion}

These results provide further evidence that in type II diabetes the hypoglycaemic effect of metformin is mediated at least partly by potentiation of insulin action, ${ }^{1}$ similar to the "extrapancreatic" mode of action proposed for sulphonylureas. ${ }^{13}$ The study also shows that metformin, like sulphonylureas, ${ }^{11} 14$ increases the number of insulin receptor binding sites in type II diabetes. In the cell model studied-the erythrocyte-metformin increased specifically the number of low affinity insulin receptors. The mechanism responsible for this increase does not appear to require the biosynthesis of new receptor protein, since erythrocytes cannot perform de novo protein biosynthesis. An increase in the availability of existing receptors is therefore proposed. The rapid onset of the effect (within one week) suggests that the recruitment of new cells into the erythrocyte pool could not account for the effect. ${ }^{15}$ Since metformin increases insulin receptor binding in vitro a direct effect on the target tissue is likely. ${ }^{23}$

Insulin resistance and impaired insulin receptor binding are characteristic of type II diabetes. ${ }^{16}$ Thus increased insulin receptor binding might contribute to the hypoglycaemic action of metformin. Additional mechanisms must be considered, however, because the number of erythrocyte insulin receptors was still raised four weeks after metformin had been withdrawn though glycaemia had returned to almost pretreatment values. Preliminary animal studies suggested that oral hypoglycaemic agents might influence postreceptor events of insulin action independently of effects at the receptor level. ${ }^{17}$ Our study provides further evidence to support this view.

We thank Professor H F Woods and Ms C A Casey, Hallamshire Hospital, Sheffield, for the plasma metformin measurements. We also acknowledge the technical help of Mr A J Kubicki.

\section{References}

${ }^{1}$ Hermann LS. Metformin: a review of its pharmacological properties and therapeutic use. Diabete Metab 1979;5:233-45.

${ }^{2}$ Holle A, Mangels W, Dreyer M, Kuhanu J, Rudiger HW. Biguanide treatment increases the number of insulin receptor sites on human erythrocytes. N Engl f Med 1981 ;305:563-6.

${ }^{3}$ Vigneri R, Pezzino V, Wong KY, Goldfine ID. Comparison of the in vitro effect of biguanides and sulfonylureas on insulin binding to its receptors in target cells. $\mathcal{F}$ Clin Endocrinol Metab 1982;54:95-101.

4 Stevens JF. Determination of glucose by an automatic analyser. Clin Chim Acta $1971 ; 32: 199-201$

5 Mallia AK, Hermanson GT, Krohn RI, Fujimoto EK, Smith PK. Preparation and use of a boronic acid affinity support for separation and quantitation of glycosylated hemoglobins. Analytical Letters $1981 ; 14$ : 649-61.

${ }^{6}$ Hales CN, Randle PJ. Immunoassay of insulin with insulin-antibody precipitate. Biochem f 1963;88:137-46.

${ }^{7}$ Lennard MS, Casey C, Tucker GT, Woods HF. Determination of metformin in biological samples. Br f Clin Pharmacol 1978;6:183-5.

${ }^{8}$ Gambhir KK, Archer JA, Bradley CJ. Characteristics of human erythrocyte insulin receptors. Diabetes $1978 ; 27: 701-8$.

${ }^{9}$ Scatchard G. The attraction of proteins for small molecules and ions. Ann NY Acad Sci 1949;51:660-72.

${ }^{10} \mathrm{Kahn}$ CR. Membrane receptors for polypeptide hormones. In: Korn ED, ed. Methods in membrane biology. Vol 3. New York: Plenum Press, 1975:81-146.

11 Beck-Nielson H, Pederson O, Linskov HO. Increased insulin sensitivity and cellular insulin binding in obese diabetics following treatment with glibenclamide. Acta Endocrinol 1979;90:451-62.

12 Ginsberg $\mathrm{BH}$. The insulin receptor: properties and regulation. In Litwack G, ed. Biochemical actions of hormones. New York: Academic Press, 1977:313-49.

${ }^{13}$ Lebovitz HE, Feinglos MN. Sulfonylurea drugs: mechanism of antidiabetic action and therapeutic usefulness. Diabetes Care 1978;1:189-98.

14 Olefsky JM, Reaven GM. Effects of sulfonylurea therapy on insulin binding on mononuclear leukocytes of diabetic patients. $\mathrm{Am} \mathbf{f} \mathrm{Med}$ 1976;60:89-95.

${ }^{15}$ Dons RF, Ryan J, Gorden P, Wachslicht-Rodbard H. Erythrocyte and monocyte insulin binding in man: a comparative analysis in normal and disease states. Diabetes $1981 ; 30: 896-902$.

16 Kolterman OG, Gray RS, Griffin J, et al. Receptor and post-receptor defects contribute to the insulin resistance in non-insulin-dependent diabetes mellitus. $\mathcal{F}$ Clin Invest 1981;68:957-69.

17 Lord JM, Atkins TW, Bailey CJ. Metformin and glibenclamide effects on hepatocyte insulin receptor binding in normal and streptozotocin diabetic mice. Diabetologia $1981 ; 21: 511$.

(Accepted 30 December 1982) 